\title{
ロードセルを用いた清酒醪の発酵速度 監視システムの試験成績
}

\author{
永谷正治・岩野君夫・三上重明・布川弥太郎 \\ （国税庁眺造試験所）
}

昭和 52 年 6 月 29 日受理

清酒醪の発酵速度は醪洰液を毎日分析することによっ て追跡するのが常法である。アルコール分の分析には多 くの試料を要し，時間および手間がかかり，さらに冓初 期では発酵槽内が不均一で分析值が変動するなどの困難 がある。一方, 初期の発酵速度の大小はその後の醪経過 に影響するところが大きい。そこで迅速簡便な発酵速度 の検出法が望まれる。柴田ら ${ }^{1)}$ は発生炭酸ガスをガスメ ーターによって計量し，アルコール生成量を計算する方 法を検討している。本報では炭酸ガスの発生による殄の 重量変化をタンクの底に設けたロードセルによって検出 する方法の試験結果を述べる。タンクにはプレートコイ ルをとりつけて温度制御も行った。

試験醸造に扮いて再現性にすぐれかつ精密な情報を得 る上に, 発酵速度の監視は有効な手段となると考兄られ る。温度制御装罡についても同様のことがいえる。した がって本報のシステムは試験醸造のみならず現場管理に も将来の利用が期待できる。

\section{試 験 方 法}

装置 第 1 図にロードセルの概要を示す。四はセルの 側面図で，平面は円型である。中心の鉄棒に荷重を受け

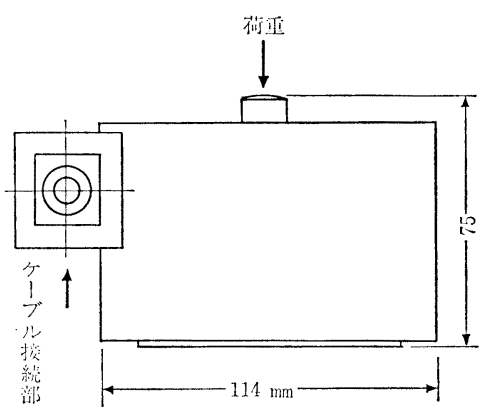

第1図口ードセルの概要（側面図） 型式: 新興通信工業(株), C 2 S 1-1 T 型 定格荷重 : $1,000 \mathrm{~kg}$

感 度 : 最大荷重の $1 / 1,000$

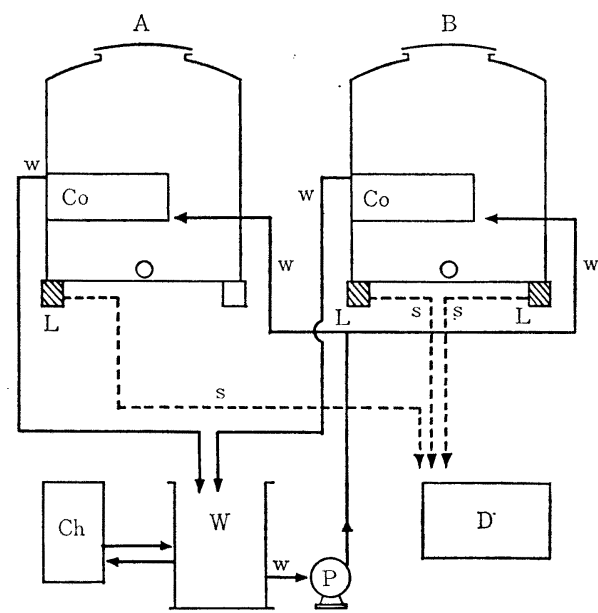

第 2 図 発酵速度監視システム
A : 第 1 発酵槽
B : 第 2 "
$\mathrm{L}:$ : ードセ
Co : プレートコイル
$\mathrm{Ch}:$ 冷 凍 機
$\mathrm{P}:$ ポンプ
$\mathrm{D}$ : 指示制御盤
$\mathrm{W}:$ 冷水タンク
$\mathrm{w}$ : 冷却水
$\mathrm{s}$ : 信 号

ると, 棒に接着された荷重-抵抗変換素子（ストレイン ゲージ）が働いて電気抵抗が変化する。これをブリッヂ 回路を通して電圧変化として信号をとり出す。

第 2 図はロードセルを設置した発醥槽システムの配置 四である。タンクは円筒型密閉, 内径 $1.44 \mathrm{~m}$, 容量 2.2 $\mathrm{k} l$, プレートコイルは $29 \mathrm{~cm} \times 250 \mathrm{~cm}\left(0.72 \mathrm{~m}^{2}\right)$, タン クとプレートコイルとで $320 \mathrm{~kg}$ である。これに保温マ ットを巻いた。第 1 発醅槽にはロードセル 1 個と木材の 台 2 個，第 2 発酵槽はロードセル 2 個と台 1 個をそれぞ れタンク円周上の $1 / 3$ の位置に怙いた 3 点支持とした。 指示はディジタル表示で第 1 , 第 2 槽はチャンネル切替 ができる。空タンクの状態で示度を 0 とし，水 $1,000 l$ を入れて示度が 500 となるように感度を調節した。すな わら示度の 1 は荷重の $2 \mathrm{~kg}$ に相当する。

温度制御系はコンプレッサー容量 $200 \mathrm{~W}$ のチラーで 
制御（水温設定は可変）した水槽内の水をポンプでプレ ートコイルを通して循環した。管路はゴム管とした。ロ ードセル調整の際にプレートコイルは満水の状態にして おいた。

醛 1 発酵槽には $51 B Y$ 醸試仕込 17 号, 第 2 槽 には同じく仕込 16 号をいずれる仲仕込から使用した。 両仕込とも総米 $370 \mathrm{~kg}$, 汲水歩合 $130 \%$, 掛米は精米 歩合 $80 \%$, 䊝米は $70 \%$, 仕込 17 号は全酵素仕込, 仕 込 16 号は䊝歩合 $20 \%$ である。酒母は両者合併で製造 した（䊝使用）。酵母は協会 7 号泡なしである。

計算法 両醪とも留即時の示度を出発点とし, 以降の 示度を差引いた差分を炭酸ガス発生による重量減と見な して下に示す換算法で純アルコール生成量を求めた。分 析值と比較するためにとの值を留即時の琴容積で割った ものをアルコール分の目安として用いた。醪の液率は 1 よりも小さいから箃密には物質収支式 ${ }^{2}$ を用いて補正し て分析值と比較せねばならない。しかし留即時のアルコ ール分を差引いた值がえられる訳であるから注意を要す る。

換算係数はグルコース 1 mole からアルコールと炭酸 ガスが各 2 mole 生成するとし, 純アルコールの密度を $0.79 \mathrm{~kg} / l$ とおいて求めた。すなわち,

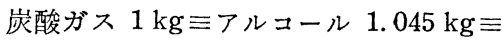

純アルコール $1.323 l$

である。

\section{結果および考察}

第 3 図上側は仕込 17 号, 同下側は仕込 16 号のいずれ も沪液中アルコール分 (分析値), 留後のアルコール増 加分（ロードセルによる）抽よ゙醪温度の経過を示す。 分析值およびロードセルに基づくアルコール分増加量は 前述のように若千比較のベースが異なるが，液率補正を しても数值的に大きな変わりはない。そこで両データの 差は留即時のアルコール分の差といらことができる。デ 一タ間に図のように曲線を描いてみると雨醪を通してロ

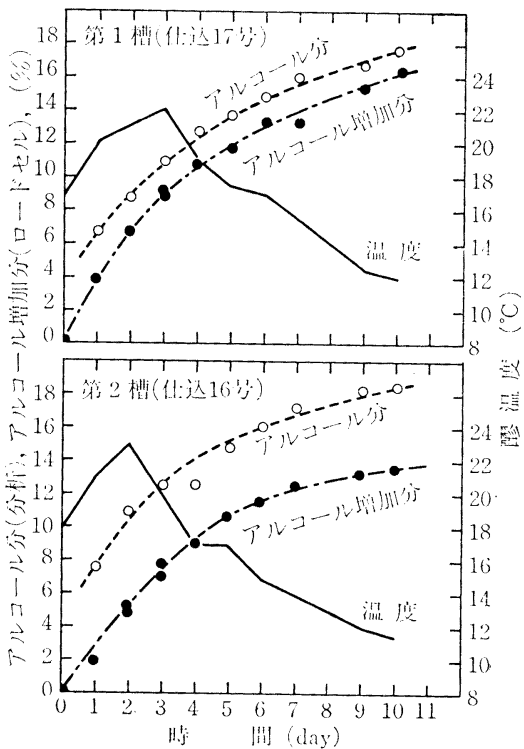

第 3 図醪発酵経過. アルニール分は常法 による分析値.

アルコール増加分はロードセルによる重量減を

アルコールに換算しそれを醪量で割ったもの.

ードセルは分析值よりも乱れが小さく，かつ両者がほぼ 一定の差を保らつつ経過していることからみてロードセ ルは発酵速度を現行の分析法と同等あるいはそれ以上正 確に検出しうることが明らかである。また，ロードセル を 1 個つけた場合（第 1 槽）と 2 個つけた場合（第 2 槽 とのデータの間に精度上みるべき差はないので，コスト つ上からも1台取りつけでじゅうぶんであろら。な稆， 醪を上槽後空槽になった時の示度は両方のタンクとも 0 に復㷌した。

以上の結果より, 清酒醪の発酵速度監視の目的には口 ードセルはじゅらぶん使用できるものと考えられる。

（本報に示した試験醸造の詳細は別に報告する）

\section{引用文献}

1) 柴田正人，私霞

2) 永谷, 水谷, 難波 : 酸工, 51, 178 (1973) 